\title{
Churritský hymnus H6 - nejstarší píseň na světě
}

Mgr. Marie Ondřičková, Ph.D.

Orientalia Antiqua Nova XXI ISBN 978-80-261-1039-2

Západočeská univerzita v Plzni, 2021 https://doi.org/10.24132/ZCU.2021.10392-78-96 


\section{Abstract}

The article was focused on the oldest description of the song on the world. In the paper was analysed content of the note score and introduced its some of translations. It also mention about its place of discovery and its discoverers. The notation was found in the North Syria at area Latákija in Ras-as-Shamrá in the west-south royal palace and its courtyards. Around 1500-1158 BC there was well-known economical and cultural advanced center Ugarit with rich existing musical tradition. Some written sources put accent the temple's singers and musicians the framework religious ceremonies. The problem of the cuneiform tablet rests on damaged some of parts, that they are not possible to translate exactly. In the tablet there are numbers whose meaning is not understandly. Today we have not to disposition only one transcription because experts are not in concordance of their metodology and this reason why individual translations are significant different so much. 


\section{Úvod}

Článek se bude věnovat nejstaršímu dochovanému hudebnímu zápisu na světě. Dlouho byla považována za nejstarší Seikilova píseň zkomponovaná okolo roku 200 až 100 př. n. l., kterou objevil v roce 1883 skotský archeolog W. M. Ramsay. ${ }^{1}$ V 50. letech 20. století se našel soubor klínopisných textů, u kterých se prokázalo, že jde o daleko starší hudební zápisy. Většina z nich jsou pouhé fragmenty. $\mathrm{K}$ nejlépe zachovaným patři hymnus $\mathrm{H} 6$. Studie o tomto hymnu seznámí čtenáře s místem nálezu, dobou, kulturou i těmi, díky nimž máme klínopisný text $\mathrm{k}$ dispozici. Tato tabulka H6 - RS $15.030+15.49+17.389$ je téměř kompletní, protože se dochovala melodie i text.

Představené výsledky badatelských aktivit významných odborníků, kteři se $v$ průběhu let tímto textem zabývali, se shoduji pouze $v$ některých bodech. Odlišnost jejich výzkumů je dána různými metodologickými přistupy, proto se přepisy do současné notové podoby tolik rozcházejí. Tento nesoulad je dán mírou poškození tabulky, proto identický překlad není možný. Částečné porozumění hudebního hymnu $\mathrm{H} 6$ umožnily objasnit i další klínopisné zápisy. Jejich obsah byl kličem k tomu, že analyzovaný text je skutečně notový part. Ale i tyto dủležité klínopisné zápisy se dochovaly pouze ve fragmentárním stavu, a tudiž také mají mnoho nesrozumitelných míst.

\section{Doba a místo vzniku tabulky}

Soubor hudebních klínopisných textů objevila archeologická expedice z Francie pod vedením C. F. Schaeffera v roce 1950 v pozůstatcích královského paláce starověkého střediska Ugarit. ${ }^{2}$

\footnotetext{
${ }^{1}$ Landels 1999, 252.
}

${ }^{2}$ Mirelman 2020, 87. 


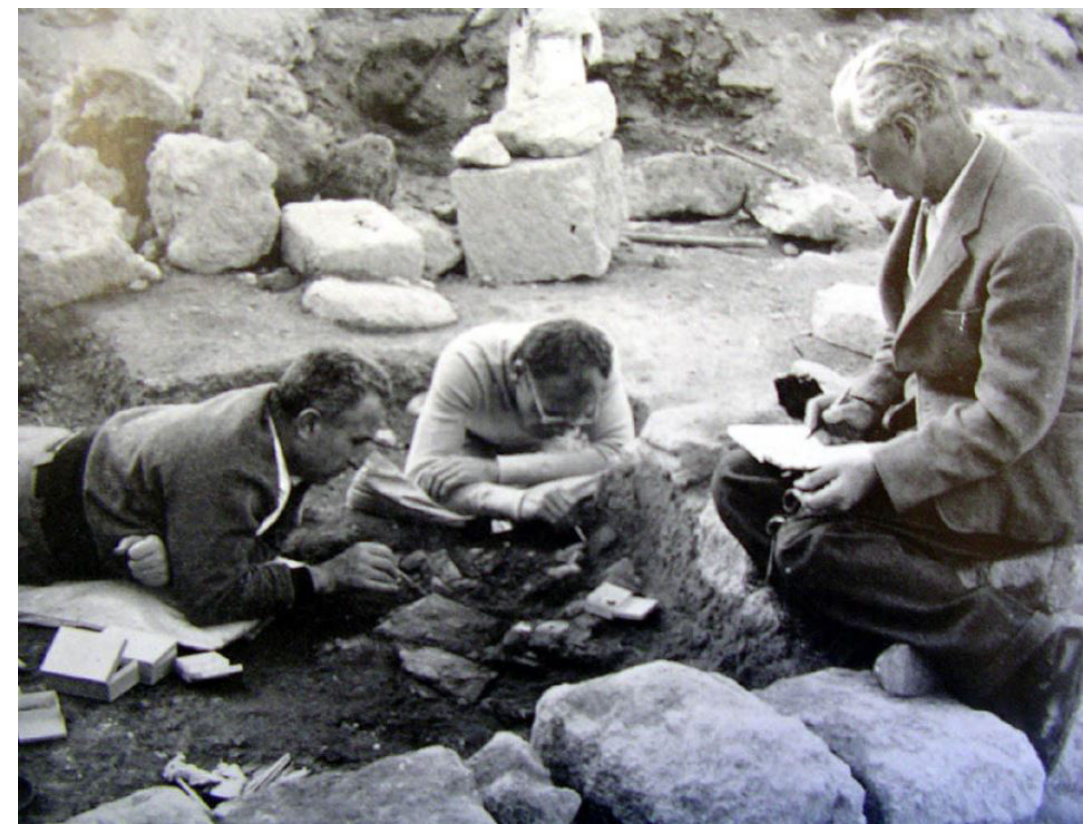

Příloha 1. Francouzští archeologové - objev tabulek 1950. Zdroj: http://users.stlcc.edu/mfuller/UgaritArchitecture.html

Toto město vzniklo okolo roku 1400 př. n. I. a zaniklo v roce 1182 př. n. I. ${ }^{3} \mathrm{~V}$ uvedeném období patřilo $\mathrm{k}$ nejvýznamnějším centrům na Blízkém východě. Rozkládalo se na území dnešní severní Sýrie, městě Ras as-Šamrá v oblasti Latákija. Tabulky objevil E. Laroche. U jejich nálezu se nejprve zkoumal jazyk, v němž byly texty zapsány. $V$ úvahu připadal západosemitský dialekt jako např́klad akkadština, kanaanejština, amorejština, aramejština či proto-hebrejština. ${ }^{4}$ Dnes už se ví, že hudební hymny byly zapsány syllabickým písmem v churritštině. ${ }^{5}$ Mezi hudební texty

\footnotetext{
${ }^{3}$ Válek 2019, 21.

${ }^{4}$ https://www.heritageforpeace.org/the-hymn-to-nikkal/.

${ }^{5}$ Válek 2019, 22.
} 


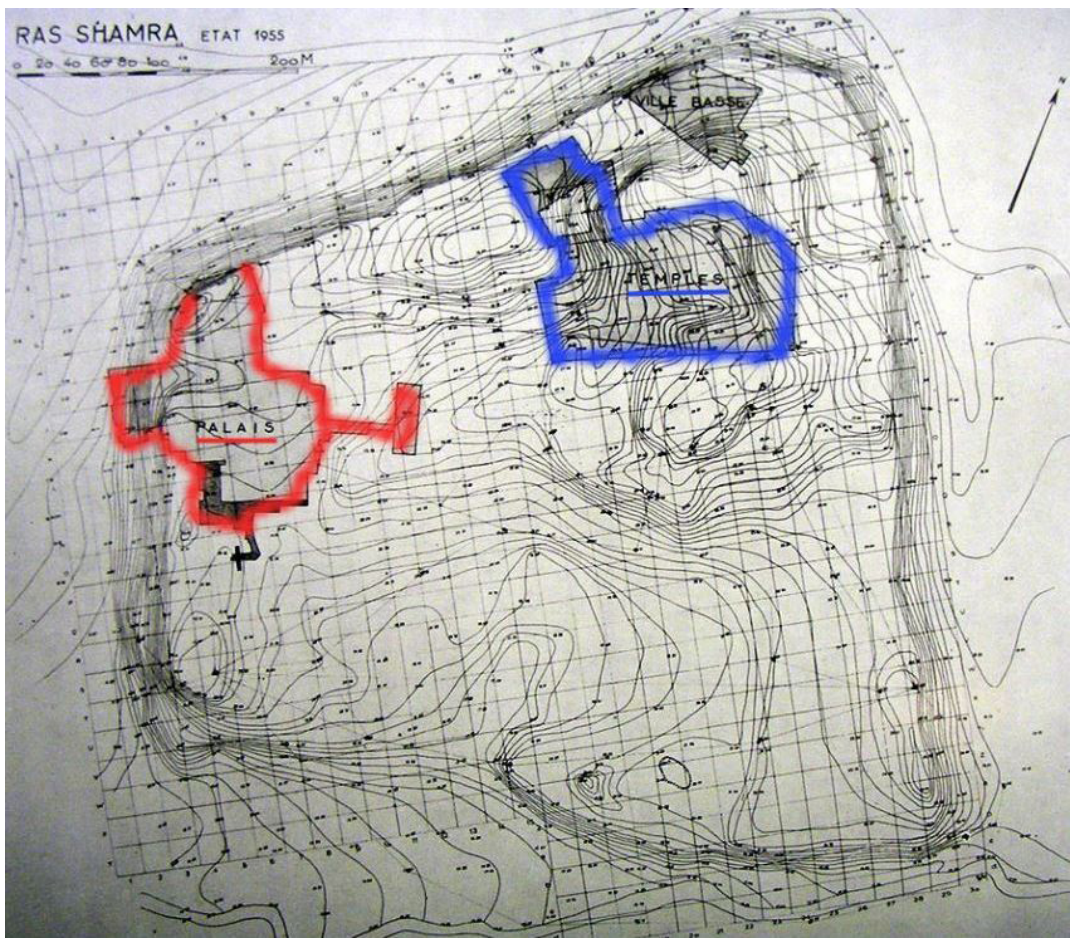

Příloha 2. Ancient Ugarit Architecture.

Topografická mapa - okrsky - palác + chrámový okrsek. Zdroj: http://users.stlcc.edu/mfuller/UgaritArchitecture.html

patři: tabulka RS 15.03 + 15.49 + 17.389, zkráceně H6, složená ze tří větších částí. Dalši se dochovaly pouze ve fragmentárním stavu - RS 14.015 (příloha 3), RS 14.018, RS18.282, RS19.084, RS 19.142-151, RS 19.153-155, 19.164 A-Z, RS 9.483. V roce 1999 M. Dietrich a W. Mayer zařadili do sbírky hudebních textů také tabulku RS 9.253. ${ }^{6}$ Také u nich se potvrdil hudební kontext. Jednalo se o písně nebo skladby určené pro konkrétní hudební

${ }^{6}$ Vita 2009, 219. 


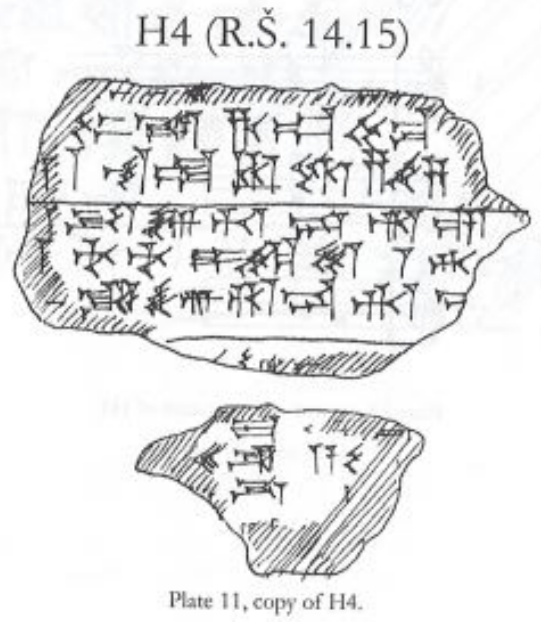

Příloha 3. Hudební klínopisná tabulka - fragment RS 14.015. Dumbrill, Richard J. 2005. The Archaeomusicology of the Near East. London: Trafford Publishing.

nástroj a přisuzuje se jim náboženská tématika. ${ }^{7}$ Tabulky se našly v královském paláci - na nádvoří, v hale či dalších komnatách. Tedy spíše v místech, kde probíhaly světské slavnosti za doprovodu pravděpodobně téhož druhu hudby. Je však vhodné starověkou hudbu ohraničit na ryze duchovní či světskou? Zvláště pokud náboženství ovlivňovalo běžné aktivity lidského bytí a naopak, u náboženských obřadů se vyskytuje i řada světských prvků - jako byly hostiny, zpěvy či tance. Jako protiargument Ize uvést, že v průběhu dalších století mohly texty změnit své místo a vyskytovat se na jiném místě, a proto hodnotit žánr z hlediska místa výskytu může být také zavádějící.

${ }^{7}$ Dietrich a Mayer 1999, 58. 


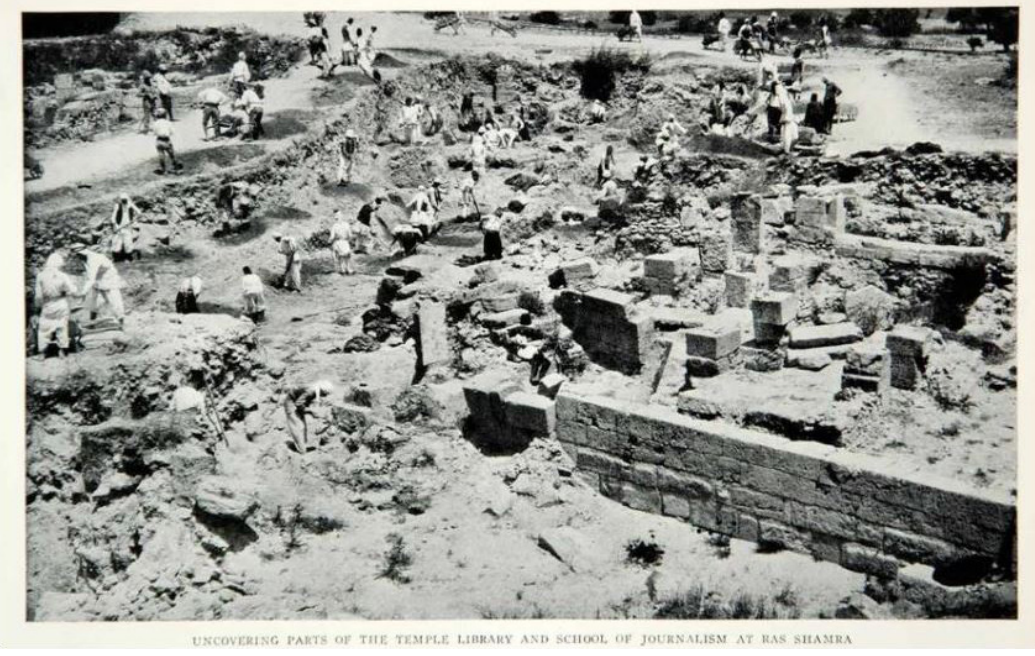

Příloha 4. Letecký snímek archeologické lokality Ugarit 1933.

Zdroj: https://www.periodpaper.com/products/1933-printarcheology-site-ras-shamra-ugarit-syria-excavation-historicalngma2-232645-ngma2-163

\section{Ugarit a jeho hudební tradice}

Písemné prameny o hudební tradici v Ugaritu $k$ tomuto dělení směřuji, nebot' jsou tu zmínky o pěvcích a pěvkyních na královských dvorech a o hudebních umělcích vystupujících v chrámech. Také tu máme zpěvačky - „plačky“, tedy ženy, které vystupovaly pouze během pohřebních rituálů.

Hudba zde, v Ugaritu, byla natolik významná, že ji přímo spravoval král, který vynakládal nemalé prostředky, aby ji mohli hudební umělci v náležité kvalitě vykonávat. „Králové byli v Ugaritu

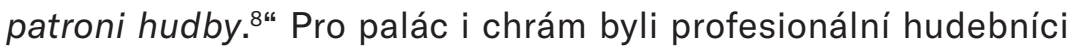

${ }^{8}$ Koitabashi 1999, 390. 
velmi důležití. Významná role krále jako patrona hudby v obou sférách opět dokazuje vzájemnou souvislost.

Hudbu v Ugaritu dokládají termíny, které potvrzuji úřad zpěváků a zpěvaček či instrumentalistů:

Dvorní hudebníci - umělci na královských dvorech Zpěvák - țb ql: CAT 1.3:l:20 Instrumentalista - n'm: CAT 1.3:I: 19

Tanečníci - habr kt tr z̧b,: CAT 1.108:5

Chrámoví hudebníci - především zpěváci a zpěvačky:

Pěvec - muž - šrm: CAT 4.126:11; LU2nâru ((LU, NAR)): PRU VI 93:24): (a) ugaritský zpěvák - (šr ugrt: CAT 4.690:37), zpěvák Aštarty (šr'țtrt: CAT 4.168:4)

Zpěvačka - žena (šrt: CAT 4.360:12)

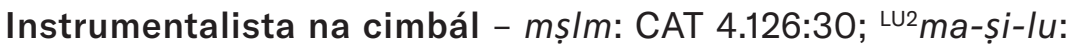
PRU vi 93:25

Naříkající ženy, tzv. „plačky“ - bkyt// mšpdt, pẓǵm: CAT 1. 19:IV:9-10. ${ }^{9}$

\section{Churritský hymnus H6}

Časové zařazení churritského hymnu H6 se u mnohých odborníků liší. Odborníci jako R. J. Dumbrill a T. H. Krispijn se přikláněji k roku 1400 př. n. l., a jiní, mezi něž patří například G. Buccellati, předpokládají, že hymnus byl psán na konci 13. stol. př. n. I., ${ }^{10}$ stejně jako M. L. West, který tabulku zařazuje do roku 1250 až 1200 př. n. I. ${ }^{11}$ I J. Blasweiler tabulku řadí spíše na konec 13. stol. př. n. Vyjadřuje to těmito slovy: „Dolní část obsahuje řadu čísel a termíny, které by mohly být interpretovány jako notový part,

\footnotetext{
${ }^{9}$ Koitabashi 1999, 379, přepis termínů dle Koitabashi.

${ }^{10}$ Válek 2019, 22.

${ }^{11}$ West 1994, 161-169.
} 

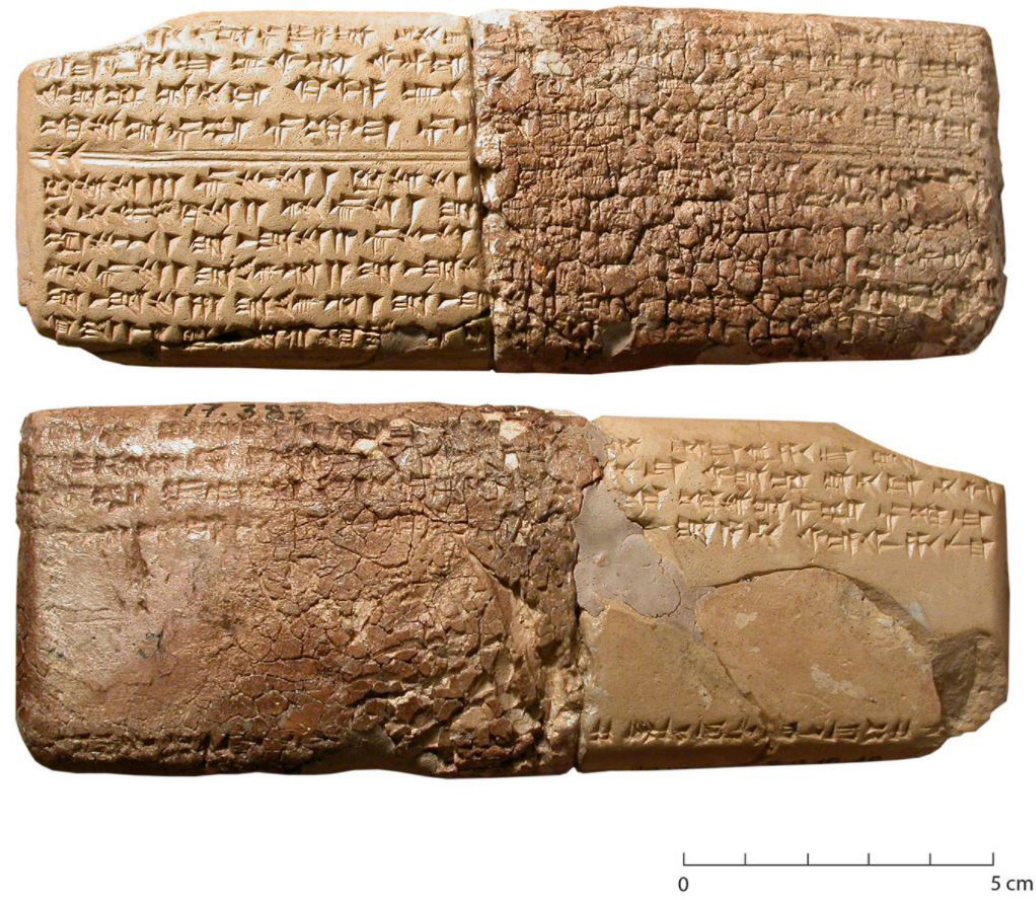

Příloha 5. Churritský hymnus H6. Zdroj:

https://www.circlethroughnewyork.com/blog/2017/2/13/ dossier-on-the-hurrian-hymn

dle něhož by měl být konkrétní hymnus zpíván... Je vhodné zdůraznit, že je hymnus napsaný v churritštině - v časech, kdy Churrité byli již na sklonku své existence."12

Z kolofonu na tabulce bylo rozluštěno jméno Ammurapi, který je považován za autora této hudební skladby. Nezjistíme již, zda ji pouze napsal, nebo byl také interpretem či instrumentalistou. ${ }^{13}$

\footnotetext{
${ }^{12}$ http://urkesh.org/urkeshpublic/music.htm.

${ }^{13}$ Mirelman 2020, 88.
} 
M. Koitabashi uvádí, že na lince 1 až 4 jsou zapsaná slova písně $v$ churritštině, ovšem velmi nesrozumitelně. Patři k horní části tabulky a vypráví přiběh ženy, která naříká nad tím, že nemůže porodit dítě, a proto se obrací k bohyni Nikkal.

Dolní část tabulky zaznamenává řadu či sérii čísel a technických názvů, které již byly interpretovány jako poměry poskytující melodii, která k hymnu patři. Tvoři ji dvojzvuky, tzv. „dichordy", ke kterým jsou připojena číla. Jsou psány akkadskými termíny v churritštině a nachází se na linkách 5 až 10 . Rovněž potvrzuje jméno písaře Ammurapiho na kolofonu tabulky. K ní přidává pojem zammarum, což znamená píseň. ${ }^{14}$ To potvrzuje také CAD, v němž je uvedeno: „zamaru znamená píseň, zpivaná s hudebním nebo bez hudebního nástroje. "15 Předpokládá, že notace je určena pro strunný hudební nástroj, možná typu „lyra“.16 Instrukce je psaná v akkadském dialektu. Slova a melodii dělí dvojitá čára.

Ústředním motivem popisované tabulky z Ugaritu je nářek $\mathrm{k}$ bohyni Nikkal - NIN.GAL. Píseň se ale nemusí nutně vztahovat $\mathrm{k}$ bohyni jako takové. Pláč se může týkat i obyčejné ženy, možná nějaké urozené dámy, která nemůže mít vlastního potomka a jen se $v$ modlitbě $k$ dotyčné bohyni obrací. Překlad P. Čecha tuto interpretaci nevylučuje. „Nikkal ji posilní, Zasnoubená jí dá porodit děti. Nechá ji porodit u jejích otců. Ale stvořitel zvolá: Neporodila dítě! [proč jsem] ti, já, žena, neporodila dítě?" Překlad je pouze částečný, je tedy možné, že hymnus může obsahovat i dalši informaci, kterou nelze z tabulky rozluštit.

\footnotetext{
${ }^{14}$ Koitabashi 1999, 377-380.

${ }^{15}$ CAD Z, 35.

${ }^{16}$ Mynářová, Čech, Antalík a Dušek 2014, 72-73.
} 


\section{Doplňující tabulky CBS 10996 a UET VII 7/80}

Uvedené zápisy CBS 10996 a UET VII 7/80 patři do tzv. hudebního babylonského systému. Obsahem těchto tabulek jsou názvy stupnic a intervalů a dávají návody, jak správně naladit strunný nástroj. Archeologické nálezy a ikonografie dokládají existenci harfy a lyry s různým počtem strun. Akkadské termíny, které jsou v tabulkách zaznamenány, se velmi podobají slovům textu H6, a potvrzuji tak jejich hudební obsah.

\section{Metodologie a výzkumné přístupy k textu H6}

Informace o prvních prepisech textu najdeme ve studii D. Wulstana vydané v roce 1971. Prvenství autor přisuzuje E. Larocheovi a H. Güterbockovi. Oba potvrdili u tabulky její hudební obsah. H. Güterbock upřesnil některé části textu. V časopise Ugaritica D. Wulstan vysvětluje, že H. Güterbock provedl korekci slova za-am-ma-as-šs a nahradil ho termínem zammarum. Totéž potvrzují i další novější vědecké práce.

D. Wulstan považuje determinované intervaly za tzv. neuma, a řeší, zda jsou klesající nebo stoupající, konjunktivní nebo disjunktivní. ${ }^{17}$ Domnívá se, že tóniny jsou ve zdvojeném kruhu, který začíná $v$ jedné stupnici a v téže končí. Jeho teorie je založena na tzv.: thetické notaci. Stupnici chápe jako kruh, kde poslední výškový stupeň je současně začátek tónové řady další.

Problém této interpretace podle O. R. Gurneyho spočivá v tom, že po osmi takovýchto postupných ladících krocích bude celý nástroj o půltón celkově naladěn výše nebo níže. ${ }^{18}$ "Thetická

\footnotetext{
${ }^{17}$ Wulstan 1971, 371.

${ }^{18}$ Gurney 1994, 102: "thetic notation, which presents the cycle as scale on a musical stave with each retuned string marked as an accidental (sharp or
} 
notace, která představuje kruh jako stupnici na notové osnově $s$ každou přeladěnou strunou označenou (zvolenou), tak, že osm po sobě jdoucích kroků by mohl být celý nástroj přeladěn o pưl tónu výše nebo niže než na začátku. "19

Další významný odborný článek publikovala A. D. Kilmerová $v$ roce 1974 (Př́loha 6). Představuje tyto hudební tabulky: CBS 10996, U 3011 = UET 7 č. 126 = NABNITU 32, KAR 158 (VAT 10101 - katalog písní - v konkrétních tóninách UET VII 74 (U. 7/80), a tedy také text nalezený v Ugaritu H6 - RS $15.30+$ 15. $49+17.387$. Stejně jako výše uvedení odborníci, i ona potvrzuje souvislost novobabylonských hudebních tabulek s textem H6, jejichž obsah se nápadně podobá. Stejně jako D. Wulstan poukazuje na prínos, $H$. Güterbocka, kterému se podařilo dokázat, že text je píseň v konkrétní tónině prostřednictvím analýzy přibuznosti termínů $v$ churritizované akkadštině $s$ akkadskými slovy z předchozích hudebních novobabylonských tabulek. ${ }^{20}$

K překladu hymnu H6 přistoupila tak, že jej rozdělila na dvě části. První, tedy horní část považuje za text písně a druhou, nacházející se pod dvěma vodorovnými linkami, za melodii. Hudební výrazy označila jako harmonické dvojzvuky - tzv. dichordy, které se opakují podle čísel uvedených za každým z nich. Horní nota představuje melodii a dolní notu považuje za doprovod. Poslední slova na reversu (na rubu), která se opakovala také na začátku obversu (líci), plní funkci refrénů. ${ }^{21}$

flat), so that eight succesive steps would be tune the whole instrument a semitone higher or lower than it started."

${ }^{19}$ Gurney 1994, 102.

${ }^{20}$ Kilmer 1984, 72.

${ }^{21}$ Duchesne-Guillemin 1984, 15: „She (A. D. Kilmerová) divided the religious text according to the written lines, taking as refrains the last words of a line on reverse which repeated at the beginning of the next line on the obverse........the musical terms were interpreted as chords of two notes ...."dichords" in which upper note is the melody while the lower one is the accompainment." 
(ifreely. $\hat{\rho}=96$ )

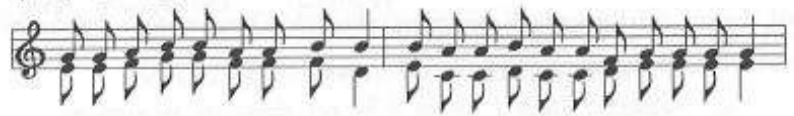

[x]-harnu-ta ni-ya-a zi- we $i-m u$-te zu-tu- ni-ya $u$-bu-ga-ra
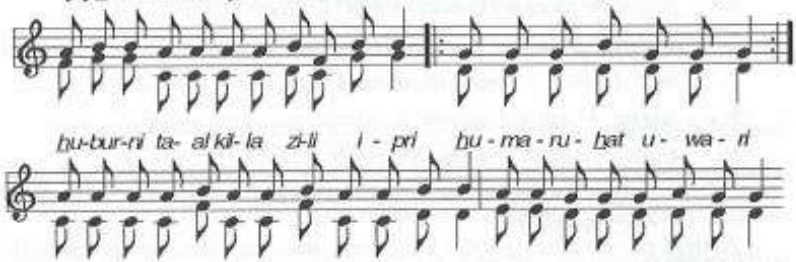

war- da-nt ta $u-k a-n$ kur-kur-ta(i)-at-la $u$-. la- li kab-gi at-lib-

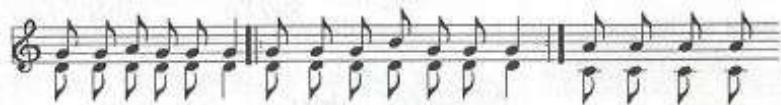

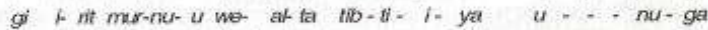

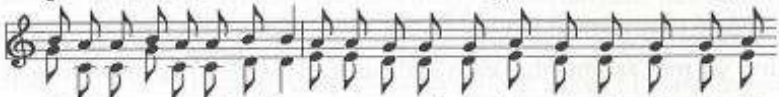

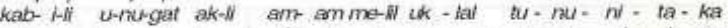

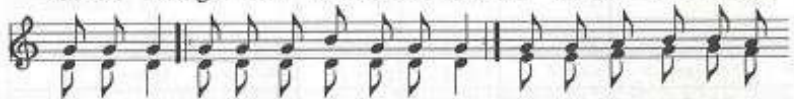

ha-nu-ka ka-li-ta-rid ní-ka-ka nebuj-ra- al ha-na ba-
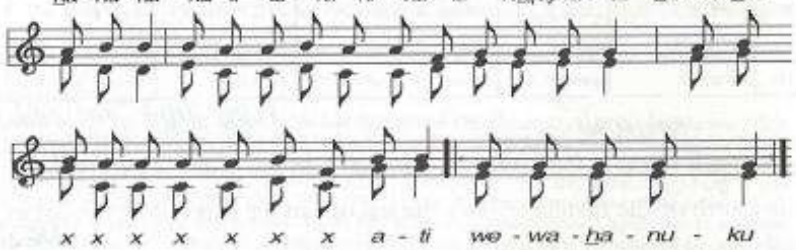

Plate 4, Kilmet's 1974 interpretation of 116.

Příloha 6. C6. Přepis hymnu H6 - A. D. Kilmer 1974. Zdroj: https://www.google.com/search?q=hurrian+hymn+h6\&client= opera\&hs=zBg\&sxsrf=ALeKkOObfAX8jzRSiYB8IOuNTw1iNOVjog: $1622367359460 \& \mathrm{tbm}=i s c h \&$ source $=i u \& i c t x=1 \& \mathrm{fir}=y S 5 Q z F O v G p$ 3ROM\%252Cve1dSPR-_ZDoSM\%252C\%252Fm\%252FOg5rb76\&vet= 1\&usg=AI4_-kSFTPCK7LMo8Dn2Z9Gwh3ZbeU5h_g\&sa=X\&ved= 2ahUKEwjegp-xjfHwAhUG-6QKHVmIDnAQ_B16BAg|EAE\#imgrc= zrpOtMIHA6FL6M\&imgdii=CrbgSIwuOfxeLM 
Další překlad nabízi M. Duchesne-Guilleminová. Hudební termíny z tabulky chápe nikoli jako dvojzvuky, ale jako části stupnice. Podle ní lze věty rozdělit pomocí enklitiky ${ }^{22}$ a tím tak zajistí shodné začátky vět se začátky melodie. Také využivá melismata,${ }^{23} \mathrm{kdy}$ se na jednu slabiku zpívá více tónů. Rytmus považuje za kolísavý a píseň celkově dělí na dva až tři rytmické celky. Přichází s hypotézou, že melodie nekončí uzavřeně. Ve svém pojednáni srovnává také svůj hudební překlad se současnou židovskou a syrochaldejskou hudební tradicí. Opírá se o to, že i v lidové židovské písni není melodie uzavřená (tendence melodii neustále opakovat). Syrochaldejské a židovské melodie bývají často rozděleny také do 3 rytmických celků, ačkoliv v churritské písni nevylučuje ani členění na části dvě. Rozsah melodie neprékračuje septimu. Jako doplňující argument pro svoji teorii uvádí, že město Ugarit se vyskytovalo v těsném sousedství s Izraelem, a tedy i hudební tradice může vykazovat podobné rysy. ${ }^{24}$

Z novějších překladů nabídneme interpretaci R. J. Dumbrilla a D. Halperina. R. J. Dumbrill (Přiloha 7) ve své teorii nabízí variantu, že hudební názvy ohraničují první a pátý tón hudebních modů, které hudební tabulka uvádí. Oproti M. Duchesne-Guilleminové upřesňuje, které části stupnice zahrnují melodii. Oproti A. D. Kilmerové zahrnuje všechny tóny - nevytváří dichordy - tedy 1. a 5. stupeň konkrétního modu. Píseň dle tohoto archeomuzikologa je postavena na rozložených pentachordech, kde každý tón je součástí tohoto intervalu se stejnou časovou hodnotou. Melodie stoupá či klesá podle principu řazení intervalů z tabulky CBS $10996 .{ }^{25}$ I tato metodologie má svoje opodstatnění.

\footnotetext{
${ }^{22}$ Enklitika - přiklonka; https://www.czechency.org/slovnik/KLITIKON [citováno 15. 5. 2021].

${ }^{23}$ Duchesne-Guillemin 1984, 21; melisma = zpěv jedné slabiky na více tónech.

${ }^{24}$ Tamtéž, 20, 21.

${ }^{25}$ Dumbrill 2005, 125.
} 
Hurrian Hymn - The Oldest Written Song - NAF

Nakai six-bole tablature for minor pentatonic flute (limited range)

Interpureind by Richand Dambinil Arnumged by Clint Geoss $d=120$
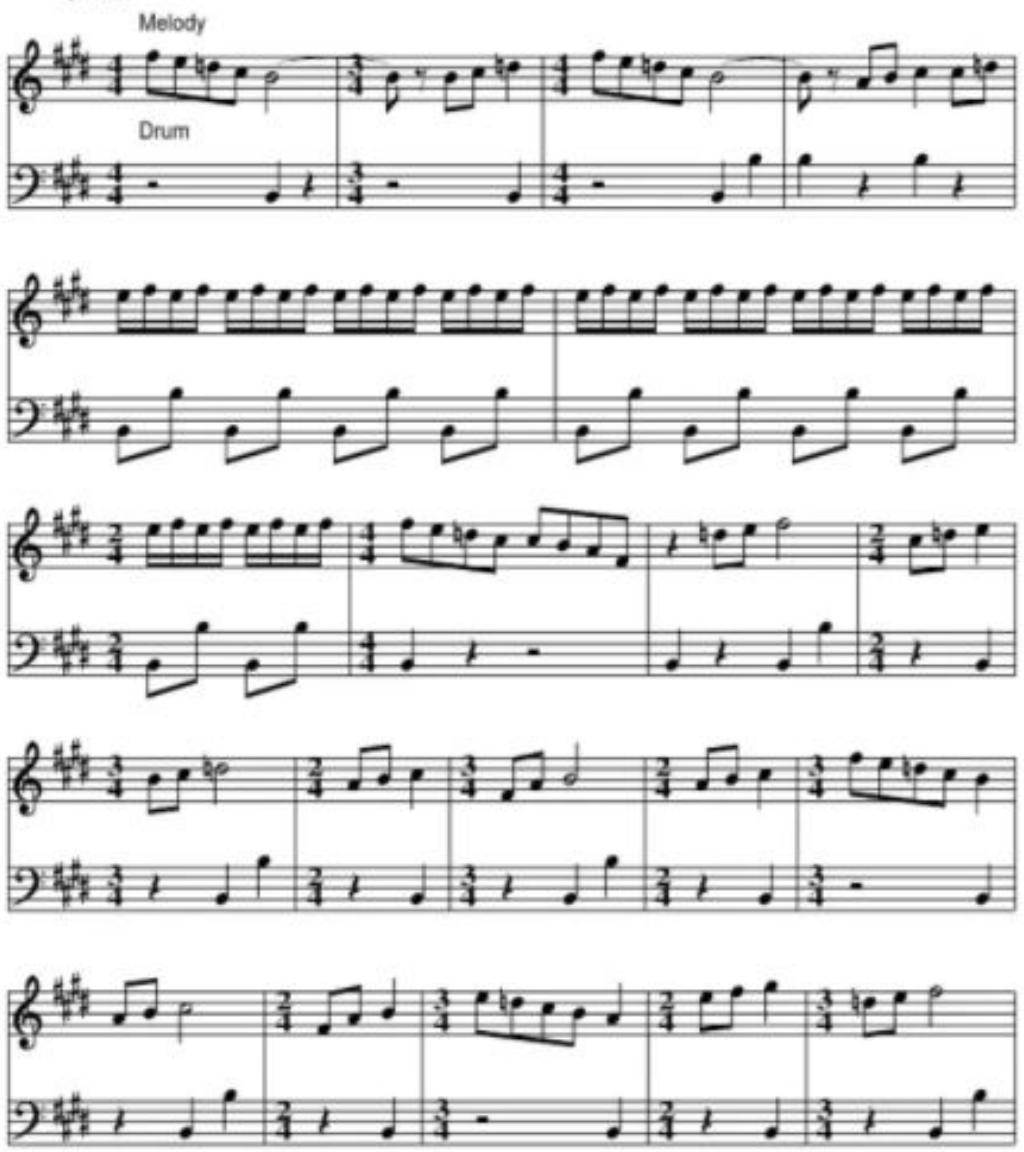

Příloha 7. Přepis hymnu H6 - R. J. Dumbrill 1999. Zdroj: https://www.scribd.com/document/382816293/A-MUSICAMAIS-ANTIGA-DO-MUNDO-Hurrian-Hymn-pdf 
Zajímavou metodu použil v roce 2008 D. Halperin, který se text pokouší rozluštit prostřednictvím kryptoanalýzy. Stejně jako předchozí odborníci i on zjištuje, že pod zdvojenou čárou se nacházejí hudební termíny, které vyjadřují výšky tónů, nebo výšky strun. Násobí intervalové vzdálenosti, které jdou za sebou. "Intervalová vzdálenost je tedy násobena takovým číslem, které odpovídá výškové vzdálenosti následujícího dichordu, a výsledný součin dá počet disjunktiv (rozložených tónových řad) k enharmonickým proměnám, které se testuji.“"26 Mody řadí cyklicky a začíná náhodně vybraným modem nidqibli, který označuje velkým tiskacím A. Přesto se domnivá, že existuje více způsobů měření intervalových vzdáleností, ale statistická spolehlivost výsledků je oslabena z důvodu, že Ize ze zápisu rozpoznat pouze 75 párů dichordů. Výškové stupně ohraničil relativně přesně, ale směr tónových řad se nedá ani prostřednictvím této metody určit.

Přístupy $\mathrm{k}$ tomuto textu se velmi liší, a stejně i tak je to s výslednými přepisy do současného notového zápisu. Představené metodologie jsou velmi zajímavé a také originální. Ani složité výpočty D. Halperina pomocí kryptoanalýzy nepřinesly jednoznačný výsledek ohledně tohoto churritského zápisu. Mají však svou odbornou hodnotu. Hypotézy se opíraji o fakta, která ani tak nestači pro věrohodný překlad či přepis.

To potvrzuje i nejnovějši výzkum Sam Mirelmanové z roku 2020, $v$ němž je uvedeno, že se dochovaný hudební text nedá přepsat do té podoby, kterou je možné zahrát či zazpivat. Ve své studii uvádí: „Všechny tyto interpretace však musí být považovány za subjektivni." Hudební tabulku vnímá jako pomůcku pro ústně

\footnotetext{
${ }^{26}$ Halperin 2008, 29, 30. „Each distance is then multiplied by the number of instances of the corresponding adjacent pairs and the sum of the product is considered as a measure of disjunctivenes for permutation or order being tested."
} 
přenášenou hudební tradici starověkého Blízkého východu. ${ }^{27}$ $\mathrm{Na}$ závěr se dá uvést, že text hymnu je píseň nebo skladba pro strunný hudební nástroj v tónině nidqibli. Všechny pojmy dolní částí hymnu jsou názvy intervalů neboli výškové vzdálenosti. $V$ tomto bodě je konsensus ve všech vědeckých analýzách.

\section{Závěr}

Samotné názvy dichordů, na nichž se všichni experti shodují, nám rozšiřuji informace o hudbě z období starověku, protože mezopotamská hudba je stále opomíjena a dodnes se setkáváme $v$ učebnicích dějin hudby $s$ některými nepřesnými informacemi, které vyplývaji spiše z neochoty tyto nové informace akceptovat. Mezopotamské umění obecně skrývá další bohatství v podobě zapsaných příb̌hů či ikonografie nejrůznějšího charakteru a odkrývání jejich tajemství patří mezi velmi obtížné badatelské aktivity, ale o to jsou větším přínosem pro širší veřejnost, protože se dozvídáme něco o kultuře z raných dějin lidstva. ${ }^{28}$

\section{Literatura}

Archi, Alfonso. 2013. „The West Hurrian Pantheon and its Backround." In Beyond Hatti. A Tribute to Gary Beckman, vyd. Billie Jean Collins a Piotr Michalowski, 1-21. Atlanta: Lockwood Press.

Dietrich, Manfried a Walter Mayer. 1999. „The Hurrian and Hittite Texts." In Handbook of Ugaritic studies, vyd. W. G. E. Watson a N. Wyatt. Leiden - Boston - Köln: Brill.

${ }^{27}$ Mirelman 2020, 88.... „Alle diese Interpretationen müssen jedoch als subjektiv“ ${ }^{28}$ Ondříčková 2018, 101. 
Duchesne-Guillemin, Marcelle. 1984. A Hurrian musical score from Ugarit: the discovery of Mesopotamian music. Malibu: Undena Publications.

Dumbrill, Richard J. 2005. The Archaeomusicology of the Near East. London: Trafford Publishing.

Dumbrill, Richard J. 2008. „Evidence and Inference in Texts of Theory in the Ancient Near East." In ICONEA 2008. Proceedings of the International Conference of Near Eastern Archaeomusicology held at the British Museum, 105-115. London: University of London.

Gordon, Cyrus, H. 1960. „Ebla, Ugarit and The Old Testament.“ Orient, 134-168 (https://doi.org/10.5356/orient1960.25.134, 21. 1. 2021).

Gurney, Oliver R. 1994. „Babylonian Music Again.“ Iraq 56: 101-106.

Halperin, David. 2008. „Musical Reconstruction of the Hurrian material by Statistical Analysis." In ICONEA 2008, Proceedings of the International Conference of Near Eastern Archaeomusicology held at the British Museum, 29-33. London: University of London.

Kilmer, Anne D. 1984. „A Music Tablet from Sippar(?): BM 65217 + 66616." Iraq 46: 69-80.

Koitabashi, M. 1999. „Music in the Text from Ugarit." Ugarit-Forschungen 30: 363-396.

Landels, John G. 1999. Music in Ancient Greece and Rome. London - New York: Routledge.

Mirelman, Sam. 2020. „Tonsysteme und Tonschriften.“ In Mus-ic-on! Klang der Antike, vyd. Oliver Wiener. Begleitband zur Ausstellung im Martin von Wagner Museum der Universität Würzburg 10. Dezember 2019 bis 12. Juli 2020, 83-90. Würzburg: Universität Würzburg.

Mynářová, Jana, Pavel Čech, Dalibor Antalík a Jan Dušek. 2014. „Záznam hudební melodie z Ugaritu.“ In Starověké písemnictví Levanty, svazek IV, 72-73. Praha: Oikoymenh. 
Ondřičková, Marie. 2018. Hudební nástroje starověkého Blízkého východu. Disertační práce, FF KBS ZČU - nepublikovaná práce.

Rahn, Ray. 2011. „Hurrian Pieces ca.1350 BCE: Part One Notation and Analyses." (https://www.researchgate.net/ publication/272494271_The_Hurrian_Pieces_ca_1350_BCE_ Part_One-Notation_and_Analysis/citation/download, 7.3. 2021). Uhliřová, Ludmila, Petr Kosta a Ludmila Veselovská. 2012. „Klitikon." In czekEncy - Nový encyklopedický slovník češtiny, vyd. Petr Karlík, Marek Nekula a Jana Pleskalová (https:// www.czechency.org/slovnik/KLITIKON, 6. 5. 2021).

Válek, František. 2019. Foreign Influences in Religion of Ancient Syria. Non-Semitic Traits in Syrian Culture in the Late Bronze Age. Diplomová práce, FF UK, Ústav filosofie a religionistiky. Vita, Juan-Pablo. 2009. „Hurrian as a living language in Ugaritic society." In Reconstructing a Distant Past. Ancient Near Eastern Essays in Tribute to Jorge R. Silva Castillo, Aula Orientalis-Supplementa 25, vyd. Diego A. Barreyra Fracaroli a Gregorio del Olmo Lete, 219-231. Sabadell - Barcelona: Editorial AUSA (https://www.academia.edu/1442458/Hurrian_as_a_living_language_in_Ugaritic_society, 31.1. 2021).

West, M. L. 1994. „The Babylonian Musical Notation and the Hurrian Melodic Texts.“ Music \& Letters 75: 161-179.

Wulstan, David. 1971. „The Earliest Musical Notation.“ Music \& Letters 52: 365-382. 